\title{
Genome-wide association analysis reveals extensive genetic overlap between mood instability and psychiatric disorders but divergent patterns of genetic effects
}

Guy Hindley (M.B.B.S.) ${ }^{1,2 *}$, Kevin S. O’Connell (Ph.D.) ${ }^{1}$, Zillur Rahman (Ph.D.) $)^{1}$, Oleksandr Frei (Ph.D.) ${ }^{1,3}$, Shahram Bahrami (Ph.D.) ${ }^{1}$, Alexey Shadrin (Ph.D.) ${ }^{1}$, Margrethe Collier Høegh (M.Sc.) ${ }^{1}$, Weiqiu Cheng (Ph.D. $)^{1}$, Naz Karadag (M.Sc.) ${ }^{1}$, Aihua Lin (PhD) ${ }^{1}$, Linn Rødevand (Cand.psychol) ${ }^{1}$, Chun C. Fan (M.D.) $)^{4,5,6}$, Srdjan Djurovic (Ph.D.) ${ }^{7,8,9}$, Trine Vik Lagerberg (Ph.D. $)^{1}$, Anders M. Dale (Ph.D.) $)^{4,5,10,11}$, Olav B. Smeland (M.D.) ${ }^{1}$, Ole A. Andreassen (M.D.) $)^{1,9^{*}}$

${ }^{1}$ NORMENT Centre, Institute of Clinical Medicine, University of Oslo and Division of Mental Health and Addiction, Oslo University Hospital, 0407 Oslo, Norway;

${ }^{2}$ Psychosis Studies, Institute of Psychiatry, Psychology and Neurosciences, King's College London, 16 De Crespigny Park, London SE5 8AB, United Kingdom

${ }^{3}$ Center for Bioinformatics, Department of Informatics, University of Oslo, PO box 1080, Blindern, 0316 Oslo, Norway, ${ }^{4}$ Department of Radiology, University of California, San Diego, La Jolla, CA 92093, United States of America; ${ }^{5}$ Multimodal Imaging Laboratory, University of California San Diego, La Jolla, CA 92093, United States of America; ${ }^{6}$ Department of Cognitive Science, University of California, San Diego, La Jolla, CA, USA; ${ }^{7}$ Department of Medical Genetics, Oslo University Hospital, Oslo, Norway; ${ }^{8}$ NORMENT Centre, Department of Clinical Science, University of Bergen, Bergen, Norway; ${ }^{9} \mathrm{KG}$ Jebsen Centre for Neurodevelopmental disorders, University of Oslo, Oslo, Norway, ${ }^{10}$ Department of Psychiatry, University of California, San Diego, La Jolla, CA, USA, ${ }^{11}$ Department of Neurosciences, University of California San Diego, La Jolla, CA 92093, United States of America.

\section{ABSTRACT}

Mood instability (MOOD) is a transdiagnostic phenomenon with a prominent neurobiological basis. Recent genome-wide association studies found significant positive genetic correlation between MOOD and major depression (DEP) and weak correlations with other psychiatric disorders. We investigated the polygenic overlap between MOOD and psychiatric disorders beyond genetic correlation to better characterize putative shared genetic determinants. Summary statistics for schizophrenia (SCZ, $\mathrm{n}=105,318)$, bipolar disorder (BIP, $n=413,466)$, DEP $(n=450,619)$, attention-deficit hyperactivity disorder (ADHD, $n=53,293)$ and MOOD $(n=363,705)$, were analysed using the bivariate causal mixture model and conjunctional false discovery rate methods to estimate the proportion of shared variants influencing MOOD and each disorder, and identify jointly associated genomic loci. MOOD correlated positively with all psychiatric disorders, but with wide variation in strength $\left(\mathrm{r}_{\mathrm{z}}=0.10-0.62\right)$. Of $10.4 \mathrm{~K}$ genomic variants influencing MOOD, $4 \mathrm{~K}-9.4 \mathrm{~K}$ were estimated to influence psychiatric disorders. MOOD was jointly associated with DEP at 163 loci, SCZ at 110, BIP at 60 and ADHD at 25, with consistent genetic effects in independent samples. Fifty-three jointly associated loci were overlapping across two or more disorders (transdiagnostic), seven of which had discordant effect directions on psychiatric disorders. Genes mapped to loci associated with MOOD and all four disorders were enriched in a single gene-set, "synapse organization". The extensive polygenic overlap indicates shared molecular underpinnings across MOOD and psychiatric disorders. However, distinct patterns of genetic correlation and effect directions of shared loci suggest divergent effects on corresponding neurobiological mechanisms which may relate to differences in the core clinical features of each disorder. 
medRxiv preprint doi: https://doi.org/10.1101/2021.07.16.21260608; this version posted July 19, 2021. The copyright holder for this preprint (which was not certified by peer review) is the author/funder, who has granted medRxiv a license to display the preprint in perpetuity.

It is made available under a CC-BY-NC-ND 4.0 International license .

\section{INTRODUCTION}

Mood instability (MOOD) is a psychological construct defined as a tendency to experience frequent, rapid fluctuations of intense affect and an inability to regulate these fluctuations or their behavioural sequelae (1). The concept was first described in people with borderline personality disorder and is a central component of the disorder (2). While present in approximately $14 \%$ of the general population (3), it is also overrepresented in several other psychiatric disorders, including schizophrenia (SCZ), bipolar disorder (BIP), depression (DEP), and attention-deficit hyperactivity disorder (ADHD) (4-7) Furthermore, MOOD is a predictor and trait-marker for both DEP and BIP $(6,8-10)$, and is associated with suicidality and poor treatment outcomes in multiple disorders $(4,11)$.

There is mounting evidence supporting a prominent neurobiological basis to MOOD. Firstly, twin studies have estimated $25 \%$ and $40 \%$ heritability for affect intensity and affective lability respectively, central components of MOOD (12). Secondly, symptoms mirroring MOOD can be caused by seizure activity or localised brain lesions, typically involving the pre-frontal cortex, the temporal lobe and the diencephalon (13). Thirdly, neuroimaging, behavioural, cognitive and electrophysiological studies have reported an array of neurobiological correlates, of which alterations in amygdala activation and connectivity between the ventromedial prefrontal cortex, amygdala and anterior cingulate cortex are the most convincing (14). In combination with its clinical significance, MOOD therefore represents a promising transdiagnostic therapeutic target that could be leveraged to develop novel treatments and inform personalized psychiatric treatment, consistent with the Research Domain Criteria framework (15). Despite this, questions remain over MOOD's neurobiological and phenomenological consistency across and within diagnostic groups, particularly in disorders such as SCZ, which is classically associated with reduced affective expression despite increased MOOD $(2,16)$.

An improved understanding of the shared genetic basis of MOOD and different psychiatric disorders may provide insights into these questions. Two large-scale GWASs of MOOD in the UK Biobank have previously identified 46 genomic loci and strong positive genetic correlations with depression, but weak positive correlations with SCZ, BIP and ADHD $(17,18)$. This has implicated several genes in MOOD 
medRxiv preprint doi: https://doi.org/10.1101/2021.07.16.21260608; this version posted July 19, 2021. The copyright holder for this preprint (which was not certified by peer review) is the author/funder, who has granted medRxiv a license to display the preprint in perpetuity.

It is made available under a CC-BY-NC-ND 4.0 International license .

which are also implicated in psychiatric disorders, including PLCL1 in SCZ, PLCL2 in BIP and NEGR1 in DEP (18-21). Nonetheless, much of the genetic basis for MOOD and psychiatric disorders remains unexplained and individual loci linked to both have yet to be examined systematically $(18,22)$. Furthermore, the identification of overlapping loci might help to disentangle the effects of different risk loci on the diverse phenomenology of psychiatric disorders and highlight neurobiological pathways with therapeutic potential (15).

To this end, we applied state-of-the-art statistical tools to summary statistics from GWAS of MOOD, SCZ, BIP, DEP and ADHD (18-21,23). We first used the bivariate causal mixture model (MiXeR) to estimate the total number of trait-influencing variants shared between MOOD and psychiatric disorders (24). Since MiXeR quantifies total genetic overlap and is unable to identify shared genomic loci, we next employed the conjunctional false discovery rate (conjFDR) method to discover loci jointly associated with MOOD and each psychiatric disorder beyond genome-wide significance (25). Unlike genetic correlation, which provides an aggregate measure for the balance of variants with concordant and discordant effects on two phenotypes, MiXeR and conjFDR are able to identify genetic overlap regardless of effect direction (26). These methods complement genetic correlation to provide a more comprehensive overview of the genetic relationships between phenotypes. Given MOOD's increased prevalence across multiple diagnostic categories, we also aimed to identify loci that were common to MOOD and more than one psychiatric disorder, representing "transdiagnostic" MOOD loci. Finally, the conjFDR method also leverages cross-phenotype enrichment to boost the power to identify novel genomic loci for each phenotype, thus contributing to efforts to unravel the "missing" heritability of psychiatric disorders $(22,25)$. 


\section{METHODS AND MATERIALS}

\section{Samples}

We acquired summary statistics from a GWAS of MOOD in the UK Biobank ( $n=363,705)(18)$. MOOD was assessed by a yes/no questionnaire item "does your mood often go up and down?" (18). While this only captures "frequent fluctuations of affect" and no other features of MOOD, e.g. affect intensity (1), a positive response has been found to be 2.5 and 14.3 times more prevalent in people with DEP and BIP compared to controls, demonstrating its clinical relevance (8). The SCZ sample comprised a metaanalysis of CLOZUK and Psychiatric Genomics Consortium (PGC) consisting of 40,675 cases and 64,643 controls (19). The DEP sample was a meta-analysis of PGC and 23andMe, Inc. samples comprising a total of 121,198 cases and 329,421 controls (21). BIP and ADHD samples were acquired from the latest PGC GWAS, comprising 41,917 cases and 371,549 controls for BIP (27) and 19,099 cases and 34,194 controls for ADHD (23). All samples were of European descent. We also included height as a non-psychiatric comparator $(\mathrm{n}=709,706)(28)$. The PGC East Asian SCZ sample (cases = 22,778, controls $=35,362)(29)$ and FinnGenn BIP $($ cases $=4,501$, controls $=192,220)$ and DEP $($ cases $=17,794$, controls $=156,611)$ samples $(30)$ were used for replication (Supplementary methods). The Norwegian Institutional Review Board: Regional Committees for Medical and Health Research Ethics (REC) South-East Norway evaluated the current protocol and found that no additional ethical approval was required because no individual data were used.

\section{Data analysis}

MiXeR v1.3 was applied to MOOD and each of SCZ, BIP, DEP, ADHD, and height (24). MiXeR first uses a univariate gaussian mixture model to quantify the polygenicity of each trait from GWAS summary statistics, expressed as the number of 'trait-influencing' variants (also referred to as 'causal' variants). Next, a bivariate gaussian mixture model is constructed to quantify the additive genetic effect of four components: 1) variants not influencing either phenotype; variants uniquely influencing either the 2) first or 3) second phenotype and 4) variants influencing both phenotypes. Results are visualised as a Venn diagram. MiXeR also calculates the genetic correlation between phenotypes and predicts the 
medRxiv preprint doi: https://doi.org/10.1101/2021.07.16.21260608; this version posted July 19, 2021. The copyright holder for this preprint (which was not certified by peer review) is the author/funder, who has granted medRxiv a license to display the preprint in perpetuity.

It is made available under a CC-BY-NC-ND 4.0 International license .

proportion of shared variants with concordant effect direction on both phenotypes. Estimates and standard errors are calculated by performing 20 iterations using 2 million randomly selected SNPs for each iteration, followed by random pruning at an linkage disequilibrium threshold of $r^{2}=0.8$. Model fit is based on likelihood maximization of signed test statistics (GWAS z-scores), evaluated by the Akaike Information Criterion (AIC) and demonstrated with modelled versus observed conditional quantilequantile (Q-Q) plots.

We next employed conjFDR to identify SNPs jointly associated with MOOD and each psychiatric disorder, which has been described previously in detail $(25,31)$. Briefly, conditional Q-Q plots were constructed to visualise cross-trait polygenic enrichment of SNP associations between MOOD and each psychiatric disorder (Supplementary methods). Cross-trait enrichment was leveraged within a Bayesian statistical framework to boost the power to discover shared genetic loci beyond genome-wide significance. Computed as the maximum of two mutual conditional FDR values (Supplementary methods), the conjFDR value provides an estimate for the posterior probability that a SNP is not associated with either trait or both traits. SNPs with a conjFDR $<0.05$ were assigned statistical significance.

The consistency of genetic effects in independent samples was evaluated using an en-masse sign concordance test (Supplementary methods) (32-34).

\section{Genomic loci definition}

Independent genomic loci jointly associated with MOOD and each psychiatric disorder were defined using the FUMA protocol (35). Significant, independent SNPs were defined as conjFDR $<0.05$ and $\mathrm{r}^{2}<0.6$. Lead SNPs were chosen if they were in approximate linkage equilibrium with each other $\left(\mathrm{r}^{2}<0.1\right)$. Transdiagnostic loci were defined as physically overlapping loci which shared at least one candidate SNP with conjFDR $\leq 0.05$ across two or more MOOD/psychiatric disorder conjunctional analyses. Effect directions within transdiagnostic loci were evaluated by comparing effect sizes of the SNP with the lowest maximum conjFDR value within the overlapping region from each MOOD/psychiatric disorder analysis, defined as the "transdiagnostic lead SNP". LD data was calculated using the European population of the 1000 genomes project reference panel (36). 
medRxiv preprint doi: https://doi.org/10.1101/2021.07.16.21260608; this version posted July 19, 2021. The copyright holder for this preprint (which was not certified by peer review) is the author/funder, who has granted medRxiv a license to display the preprint in perpetuity.

It is made available under a CC-BY-NC-ND 4.0 International license .

\section{Functional annotation}

Candidate SNPs, defined as any SNP within each jointly associated genomic locus with a conjFDR value $<0.10$ and an $L D r^{2} \geq 0.6$ with an independent significant SNP, were functionally annotated using FUMA (35). A lower conjFDR threshold for candidate SNPs was employed to maximise the probability that putative causal SNPs are captured for functional annotation, consistent with previous primary GWAS (33) and conjFDR studies (37). SNPs were mapped to putative causal genes using three strategies: a) positional mapping b) expression quantitative trait locus (eQTL) mapping and c) chromatin interaction mapping(35). We defined a subset of "credible mapped genes" as those that were mapped by all three strategies. We conducted Gene Ontology gene-set analyses using FUMA (35) on credible mapped genes for each MOOD/psychiatric disorder pair. See Supplementary methods for further details.

\section{Data availability}

All GWAS summary statistics are publicly available besides 23andMe DEP data (Supplementary methods). The code for all analyses can be accessed at https://github.com/precimed.

\section{RESULTS}

\section{Using MiXeR to estimate total polygenic overlap}

Univariate MiXeR demonstrated MOOD to be highly polygenic, with $10.4 \mathrm{~K}(\mathrm{SD}=0.4 \mathrm{~K}$ ) variants predicted to influence MOOD, comparable to the complex polygenic architectures of psychiatric disorders (Supplementary table 1, Supplementary figure 1).

Bivariate MiXeR analysis revealed substantial overlap between MOOD and all four disorders (Figure la, Supplementary table 1), both in the presence of moderate positive genetic correlation (DEP and ADHD) and minimal genetic correlation (SCZ and BIP). This occurs due to a pattern of mixed effect directions among shared variants, i.e. a balance of variants with concordant and discordant effects on each trait cancel each other out resulting in minimal correlation despite extensive polygenic overlap. For example, the overlap between $\mathrm{SCZ}$ and MOOD was particularly striking, with $9.4 \mathrm{~K}(\mathrm{SD}=0.4 \mathrm{~K})$ shared variants, representing 97\% variants influencing SCZ and 90\% variants influencing MOOD, 
medRxiv preprint doi: https://doi.org/10.1101/2021.07.16.21260608; this version posted July 19, 2021. The copyright holder for this preprint (which was not certified by peer review) is the author/funder, who has granted medRxiv a license to display the preprint in perpetuity.

It is made available under a CC-BY-NC-ND 4.0 International license .

despite weak positive genetic correlation $\left(\mathrm{r}_{\mathrm{g}}=0.11, \mathrm{SE}=0.0089\right)$. There was also weak positive genetic correlation $\left(\mathrm{r}_{\mathrm{g}}=0.10, \mathrm{SE}=0.0096\right)$ but fewer shared variants between BIP and MOOD, with $7.8 \mathrm{~K}$ $(\mathrm{SD}=0.6 \mathrm{~K})$ shared variants which represented smaller proportions of trait-influencing variants $(91 \%$ and $75 \%$ for BIP and MOOD respectively). The proportions of shared variants predicted to have concordant effects on MOOD and each of SCZ (54\%, SD=0.4\%) and BIP (57\%, SD=0.5\%) were consistent with extensive overlap and weak genetic correlation.

In comparison, $\mathrm{DEP}\left(\mathrm{r}_{\mathrm{g}}=0.62, \mathrm{SE}=0.011\right)$ and $\mathrm{ADHD}\left(\mathrm{r}_{\mathrm{g}}=0.38, \mathrm{SE}=0.012\right)$ possessed stronger positive genetic correlations with MOOD (replicating previous findings in DEP) (18). A total of $7.7 \mathrm{~K}$ $(\mathrm{SD}=0.3 \mathrm{~K})$ variants were estimated to be shared between DEP and MOOD, representing 55\% DEPinfluencing variants and 74\% MOOD-influencing variants. The high number of DEP-specific variants relative to the other disorders $(6.3 \mathrm{~K}, \mathrm{SD}=0.5 \mathrm{~K}, 45 \%)$ was likely due to DEP's extensive polygenicity $(14 \mathrm{~K}, \mathrm{SD}=0.6 \mathrm{~K})$ and may relate to the clinical heterogeneity of the disorder $(24,38)$. ADHD was found to share $4 \mathrm{~K}(\mathrm{SD}=0.6 \mathrm{~K})$ variants, representing $71 \% \mathrm{ADHD}$ influencing variants and $38 \% \mathrm{MOOD}$ influencing variants. The high proportion of MOOD-specific variants $(6.4 \mathrm{~K}, 0.6 \mathrm{~K}, 62 \%)$ is related to ADHD's lower polygenicity $(5.6 \mathrm{~K}, \mathrm{SD}=0.4 \mathrm{~K})$ relative to MOOD. Consistent with the stronger positive genetic correlations, there were higher proportions of shared variants predicted to have concordant effects, with 94\% ( $\mathrm{SD}=2.8 \%$ ) concordant for $\mathrm{DEP}$ and MOOD and 77\% (SD=6\%) for ADHD and MOOD. Given the extensive polygenic overlap across phenotypes, we applied the MiXeR model to height and MOOD as a non-psychiatric comparator. MiXeR estimated $0.8 \mathrm{~K}(0.2 \mathrm{~K})$ shared variants and minimal negative correlation $\left(\mathrm{r}_{\mathrm{g}}=-0.08, \mathrm{SE}=0.0083\right)$. AIC and conditional QQ plots to assess MiXeR model fit are described in Supplementary results.

The relationship between the number of shared variants and genetic correlation is illustrated in density plots in Figure $1 b$, in which the effect of each variant on MOOD is plotted against its effect on each psychiatric disorder and height. For SCZ and BIP, a large proportion of variants effect both phenotypes (oval) but these are distributed evenly between regions indicating concordant effects (top-right and bottom-left quadrants) and discordant effects (top-left and bottom-right quadrants). The effects of overlapping SNPs cancel each other out leading to weak genetic correlation despite substantial overlap. 
medRxiv preprint doi: https://doi.org/10.1101/2021.07.16.21260608; this version posted July 19, 2021. The copyright holder for this preprint (which was not certified by peer review) is the author/funder, who has granted medRxiv a license to display the preprint in perpetuity.

It is made available under a CC-BY-NC-ND 4.0 International license.

For DEP and ADHD, most variants have concordant directions, illustrated by the preponderance of variants in the top-right and bottom-left quadrants. This results in polygenic overlap and stronger positive genetic correlations. The MOOD and height subplot reveals that most variants affecting one trait do not influence the other and vice versa. Almost all associated variants are therefore plotted close to $\beta=0$ for one or the other phenotype (horizontal and vertical lines), indicating minimal genetic overlap and weak genetic correlation.

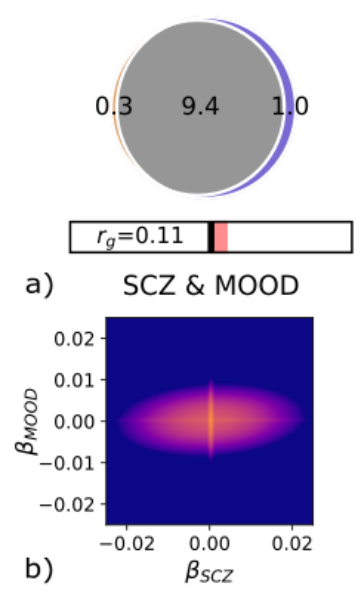

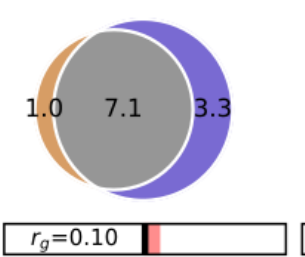
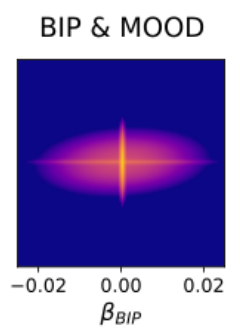

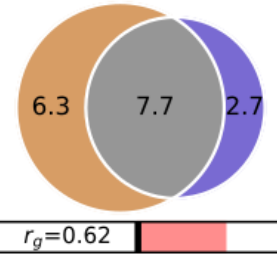

DEP \& MOOD

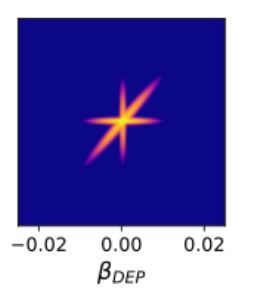

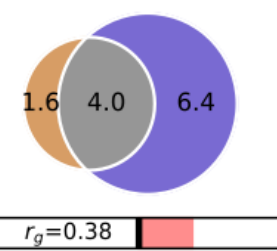

ADHD \& MOOD

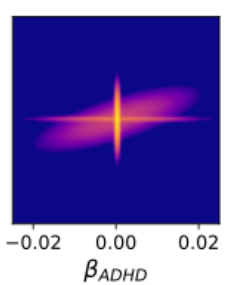

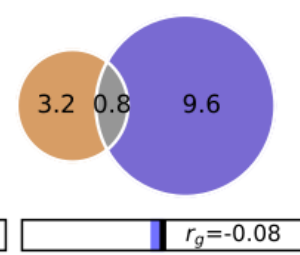

HEIGHT \& MOOD

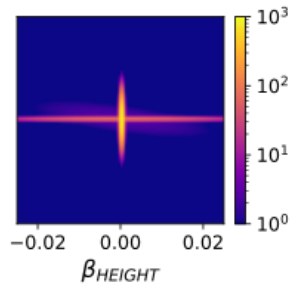

Figure 1: a) Total number of shared variants between mood instability (MOOD, blue) and schizophrenia (SCZ), bipolar disorder (BIP), major depression (DEP), attention-deficit hyperactivity disorder (ADHD) and height as estimated by MiXeR. Venn diagrams representing the proportion of unique and shared variants associated with MOOD and each of SCZ, DEP, BIP, ADHD and height. Polygenic overlap is represented in grey. The numbers indicate the estimated quantity of variants in thousands per component that explains $90 \%$ of SNP heritability for each phenotype. The size of the circle reflects the extent of polygenicity for each trait. Genetic correlation $\left(\mathrm{r}_{\mathrm{g}}\right)$ is represented in the horizontal bars beneath the Venn diagrams. Right of the central bar (red) indicates positive $r_{g}$ and left of the central bar (blue) indicates negative $r_{g}$. $\boldsymbol{b}$ ) MiXeR density plots illustrating the effect sizes of variants ( $\beta$, $\mathrm{x}$ and $\mathrm{y}$ axes) influencing MOOD and each of SCZ, BIP, DEP, ADHD, and height respectively, with respect to the number of variants (colour scale, blue to yellow). Extensive polygenic overlap of concordant and discordant variants is observed for MOOD and SCZ and BIP. The plots of MOOD and ADHD and DEP also illustrate extensive polygenic overlap, but most variants have concordant effects. The plot of MOOD and height indicates that most variants influencing each trait have little to no effect on the other. 
medRxiv preprint doi: https://doi.org/10.1101/2021.07.16.21260608; this version posted July 19, 2021. The copyright holder for this preprint (which was not certified by peer review) is the author/funder, who has granted medRxiv a license to display the preprint in perpetuity.

It is made available under a CC-BY-NC-ND 4.0 International license .

\section{Identifying genomic loci shared between MOOD and psychiatric disorders}

We computed conjFDR values for each SNP present in both primary GWASs. The conjFDR value is interpreted as a conservative estimate for the probability that a given SNP is not associated with either phenotype. By leveraging cross-trait enrichment and employing a Bayesian statistical framework (Supplementary figures 3-4), conjFDR identifies jointly associated loci beyond genome-wide significance.

At conjFDR $<0.05$, MOOD was jointly associated with SCZ at 102 independent genomic loci, BIP at 60 loci, DEP at 163 loci, and ADHD at 28 loci (Table 1, Supplementary table 2). Among these, 246 were novel in MOOD, 26 in SCZ, 22 in BIP, 92 in DEP and 12 in ADHD, demonstrating conjFDR's ability to boost the power to discover novel loci. On comparing the effect direction of jointly associated lead SNPs, 58.9\% (60/102) were concordant for SCZ and MOOD, 65.0\%\% (39/60) for BIP and MOOD, 96.3\% (157/163) for DEP and MOOD and 96\% (27/28) for ADHD and MOOD. These figures closely resemble the MiXeR estimates for MOOD and SCZ (54\%), BIP (54\%) and DEP (94\%) but are somewhat discrepant from the estimate for MOOD and ADHD (77\%). This is likely due to the small number of loci identified in this analysis. Functional annotation analyses for individual analyses are presented in Supplementary results.

\section{Consistency of genetic effects in independent samples}

When comparing the effect directions of lead SNPs in discovery and replication samples, there was significant en masse sign concordance for SCZ (74/96 concordant; $\left.\mathrm{p}=4.72 \mathrm{e}^{-8}\right)$, BIP (39/56 concordant; $\mathrm{p}=0.0023)$ and DEP $\left(121 / 154\right.$ concordant; $\left.\mathrm{p}=2.63 \mathrm{e}^{-13}\right)$. The discrepancy in the number of lead SNPs was due to missing lead SNPs in replication samples ( $\mathrm{SCZ}=6$; $\mathrm{BIP}=4$; $\mathrm{DEP}=9)$. We did not have access to sufficiently large independent datasets for MOOD or ADHD. 
medRxiv preprint doi: https://doi.org/10.1101/2021.07.16.21260608; this version posted July 19, 2021. The copyright holder for this preprint (which was not certified by peer review) is the author/funder, who has granted medRxiv a license to display the preprint in perpetuity.

It is made available under a CC-BY-NC-ND 4.0 International license .

\section{Identifying and characterising transdiagnostic loci}

A total of 53 loci were associated with MOOD and two or more psychiatric disorders (Supplementary table 9). Among these, 38 were associated with MOOD and two disorders, 11 with MOOD and three disorders and four with MOOD and all four disorders. Seven transdiagnostic loci had divergent effect directions on psychiatric disorders, but BIP was always concordant with SCZ $(n=27)$ and DEP was always concordant with ADHD ( $\mathrm{n}=18)$. The distribution of these loci is summarised in Figure 2. Loci overlapping across three or more psychiatric disorders are presented in Table 2.

\begin{tabular}{|c|c|c|c|c|c|c|c|}
\hline Psych & $\begin{array}{c}\text { Psych } \\
\text { GWAS (n) }\end{array}$ & $\begin{array}{c}\text { Joint loci with } \\
\text { MOOD at } \\
\left(p<5 x 10^{-8}\right) \\
\end{array}$ & $\begin{array}{c}\text { Joint loci with } \\
\text { MOOD at } \\
(\text { conjFDR }<0.05) \\
\end{array}$ & $\begin{array}{l}\text { Novel loci in } \\
\text { MOOD (n) }\end{array}$ & $\begin{array}{l}\text { Novel loci } \\
\text { in Psych (n) }\end{array}$ & $\begin{array}{l}\text { Replicated loci } \\
\text { (sign test) (n) }\end{array}$ & $\begin{array}{c}\text { Transdiagnostic } \\
\text { loci (n) }\end{array}$ \\
\hline$\overline{S C Z}$ & 105,318 & 40 & 102 & 71 & 26 & 74 & 41 \\
\hline BIP & 413,463 & 5 & 60 & 42 & 22 & 39 & 35 \\
\hline DEP & 450,619 & 29 & 163 & 140 & 92 & 121 & 38 \\
\hline ADHD & 53,293 & 2 & 28 & 17 & 12 & N/a & 11 \\
\hline
\end{tabular}

Table 1: Summary of the total number of loci jointly associated with mood instability (MOOD) and each of psychiatric disorders (Psych) schizophrenia (SCZ), bipolar disorder (BIP), major depression (DEP) and attention-deficit hyperactivity disorder (ADHD), number of novel loci in each phenotype, number of loci with concordant effect directions in discovery and replication samples, and number of transdiagnostic loci (overlapping between two or more Psych) identified using the conjunctional false discovery rate (conjFDR) method at a threshold of conjFDR $<0.05$. The sample sizes of the original Psych GWAS and the number of overlapping loci at genome-wide significance in the original GWAS $\left(5 \times \mathrm{xp}<10^{-8}\right)$ are provided for comparison.

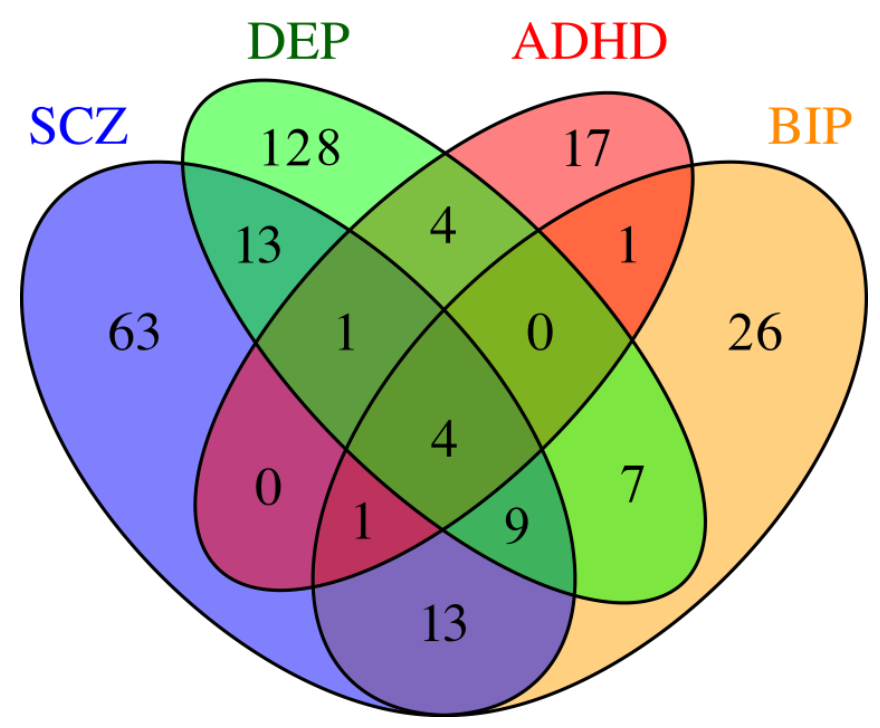

Figure 2: The distribution of transdiagnostic mood instability loci. Venn diagram showing the numbers of diagnosis-specific and transdiagnostic loci across each MOOD and psychiatric disorder conjFDR analysis (SCZ=schizophrenia, BIP= bipolar disorder, $\mathrm{DEP}=$ major depression, and $\mathrm{ADHD}=$ attention-deficit hyperactivity disorder). 
medRxiv preprint doi: https://doi.org/10.1101/2021.07.16.21260608; this version posted July 19, 2021. The copyright holder for this preprint (which was not certified by peer review) is the author/funder, who has granted medRxiv a license to display the preprint in perpetuity.

It is made available under a CC-BY-NC-ND 4.0 International license .

We next identified 1179 genes that were mapped to candidate SNPs from two or more psychiatric disorder/MOOD pairs, 64 of which were mapped by all three strategies (Supplementary table 7). Figure 2 illustrates the chromosomal distribution of the shared loci for each phenotypic pairing alongside mapped genes for each transdiagnostic locus overlapping across three or more disorders. Among these, VRK2, KIAA1109, AC110781.3, PCLO, TMPRSS5 and EP300 were all mapped to non-synonymous exonic SNPs. Furthermore, VRK2, AC110781.3 and EP300 were mapped by all three mapping strategies, including eQTLs in the substantia nigra (VRK2), caudate, hypothalamus and nucleus accumbens (AC110781.3) and the cerebellum and hypothalamus (EP300). VRK2 is a serine threonine kinase which has previously been implicated in SCZ, BIP and DEP and plays a role in neuronal proliferation and migration (39). AC110781.3 is a gene of unknown function expressed within 13 different brain tissues, with greatest expression in the cortex, amygdala, and hippocampus (Supplementary figure 5). It was also mapped to a locus associated with all four disorders, but with opposite effect directions on SCZ and BIP vs DEP and ADHD. Finally, EP300 is a histone acetyltransferase implicated in cell proliferation and differentiation. Other notable genes mapped to transdiagnostic loci include the dopamine receptor D2 gene (DRD2), the calcium channel voltage-gated channel subunit $C A C N A I C$, and the neuron specific potassium/chloride transporter SLC12A5.

A single gene-set, "Synapse organization" was significantly enriched with mapped genes from all four analyses. There were a further 6 gene-sets enriched with mapped genes for MOOD and each of SCZ, BIP and DEP, although there was extensive overlap in genes across the different gene-sets. All genesets besides "Neuron part" were either directly or indirectly related to synaptic structure ("Synapse", "Synapse part", "Postsynapse”, "Synaptic membrane", “cell projection part”) (Supplementary table 8), Interestingly, when linking mapped genes from each gene-set back to their associated genomic locus, there was a divergent pattern of effect directions with SCZ (51.4-61.8\%) and BIP (58.3-70.6\%) showing a pattern of mixed effect directions with MOOD, while DEP (97.4-100\%) and ADHD (100\%) were almost entirely concordant. This is consistent with the patterns of effect directions estimated by MiXeR and observed in jointly associated loci identified by conjFDR (Supplementary table 10). This indicates that the divergent pattern of effect directions persists at the level of specific gene-sets. 
medRxiv preprint doi: https://doi.org/10.1101/2021.07.16.21260608; this version posted July 19, 2021. The copyright holder for this preprint (which was not certified by peer review) is the author/funder, who has granted medRxiv a license to display the preprint in perpetuity. It is made available under a CC-BY-NC-ND 4.0 International license

\begin{tabular}{|c|c|c|c|c|c|c|c|c|}
\hline Chr & Psych & Min-max BPs & $\begin{array}{l}\text { Trans- } \\
\text { diagnostic } \\
\text { lead SNP }\end{array}$ & conjFDR & $\begin{array}{c}\text { Concordant } \\
\text { effects }\end{array}$ & $\begin{array}{l}\text { Novel } \\
\text { in } \\
\text { Psych }\end{array}$ & $\begin{array}{l}\text { Novel in } \\
\text { MOOD }\end{array}$ & Mapped genes \\
\hline 2 & $\begin{array}{c}\text { SCZ } \\
\text { BIP } \\
\text { DEP } \\
\text { ADHD }\end{array}$ & $\begin{array}{l}22430795-22545027 \\
22430795-22606275 \\
22430795-22606275 \\
22430795-22493637\end{array}$ & rs 13387284 & $\begin{array}{l}0.029 \\
0.035 \\
0.010 \\
0.029\end{array}$ & $\begin{array}{l}\text { TRUE } \\
\text { TRUE } \\
\text { TRUE } \\
\text { TRUE }\end{array}$ & $\begin{array}{l}\mathrm{X} \\
\mathrm{X} \\
\mathrm{X} \\
\mathrm{X}\end{array}$ & TRUE & AC068490.2 $2^{a}$ \\
\hline 2 & $\begin{array}{l}\text { SCZ } \\
\text { BIP } \\
\text { DEP }\end{array}$ & $\begin{array}{l}57942987-58505679 \\
57956088-58444610 \\
57942987-58484172\end{array}$ & rs2717039 & $\begin{array}{l}0.029 \\
0.032 \\
0.010\end{array}$ & $\begin{array}{l}\text { TRUE } \\
\text { TRUE } \\
\text { TRUE }\end{array}$ & $\begin{array}{l}x \\
x \\
x\end{array}$ & $\mathrm{x}$ & VRK2, FANCL, BCL11A \\
\hline 4 & $\begin{array}{l}\mathrm{SCZ} \\
\mathrm{BIP} \\
\mathrm{DEP}\end{array}$ & $\begin{array}{l}122913532-123558330 \\
123026869-123558330 \\
123052343-123558330\end{array}$ & rs10014468 & $\begin{array}{c}0.019 \\
0.0048 \\
0.0015\end{array}$ & $\begin{array}{c}x \\
x \\
\text { TRUE }\end{array}$ & $\begin{array}{l}x \\
x \\
x\end{array}$ & $\mathrm{x}$ & TRPC3, KIAA1109, IL21 \\
\hline 5 & $\begin{array}{c}\text { SCZ } \\
\text { BIP } \\
\text { DEP } \\
\text { ADHD }\end{array}$ & $\begin{array}{l}103791044-104055261 \\
103671867-104082179 \\
103671867-104082179 \\
103671867-104082179\end{array}$ & rs2447832 & $\begin{array}{l}0.044 \\
0.036 \\
0.013 \\
0.033\end{array}$ & $\begin{array}{l}\text { TRUE } \\
\text { TRUE } \\
\text { TRUE } \\
\text { TRUE }\end{array}$ & $\begin{array}{l}\mathrm{X} \\
\mathrm{X} \\
\mathrm{X} \\
\mathrm{X}\end{array}$ & $\mathrm{x}$ & RP11-6N13. ${ }^{a}, C T D-2374 C 24.1^{a}$ \\
\hline 7 & $\begin{array}{c}\text { SCZ } \\
\text { BIP } \\
\text { DEP } \\
\text { ADHD }\end{array}$ & $\begin{array}{l}1873756-2110850 \\
1882795-2110850 \\
1860733-2247403 \\
1873756-2110850\end{array}$ & rs55790766 & $\begin{array}{l}0.026 \\
0.011 \\
0.005 \\
0.037\end{array}$ & $\begin{array}{c}x \\
x \\
\text { TRUE } \\
\text { TRUE }\end{array}$ & $\begin{array}{l}\mathrm{X} \\
\mathrm{X} \\
\mathrm{X} \\
\mathrm{X}\end{array}$ & $\mathrm{x}$ & $\begin{array}{l}\text { AC110781.3, INTS1, MAFK, } \\
\text { TMEM184A, PSMG3, ELFN1, } \\
\text { MAD1L1, FTSJ2, NUDT1 }\end{array}$ \\
\hline 7 & $\begin{array}{l}\text { SCZ } \\
\text { BIP } \\
\text { DEP }\end{array}$ & $\begin{array}{l}82386297-82641937 \\
82376952-82555669 \\
82386297-82557937\end{array}$ & rs2158220 & $\begin{array}{c}0.006 \\
0.01 \\
0.012\end{array}$ & $\begin{array}{l}\text { TRUE } \\
\text { TRUE } \\
\text { TRUE }\end{array}$ & $\begin{array}{l}\mathrm{x} \\
\mathrm{x} \\
\mathrm{x}\end{array}$ & TRUE & $H G F, P C L O$ \\
\hline 8 & $\begin{array}{l}\text { SCZ } \\
\text { BIP } \\
\text { DEP }\end{array}$ & $\begin{array}{c}8088230-11417790 \\
7632319-11830150 \\
10121605-10435915\end{array}$ & rs2952245 & $\begin{array}{l}0.028 \\
0.044 \\
0.036\end{array}$ & $\begin{array}{c}\mathrm{x} \\
\mathrm{x} \\
\text { TRUE }\end{array}$ & $\begin{array}{l}\mathrm{X} \\
\mathrm{X} \\
\mathrm{X}\end{array}$ & $\mathrm{x}$ & $M R S A^{c}$ \\
\hline 10 & $\begin{array}{c}\text { SCZ } \\
\text { BIP } \\
\text { DEP } \\
\text { ADHD }\end{array}$ & $\begin{array}{l}106453832-106640653 \\
106455520-106640653 \\
106405854-106830537 \\
106392549-106640653\end{array}$ & rs2496014 & $\begin{array}{l}0.016 \\
0.022 \\
0.006 \\
0.016\end{array}$ & $\begin{array}{l}\text { TRUE } \\
\text { TRUE } \\
\text { TRUE } \\
\text { TRUE }\end{array}$ & $\begin{array}{l}\mathrm{X} \\
\mathrm{X} \\
\mathrm{X} \\
\mathrm{X}\end{array}$ & $\mathrm{x}$ & SORCS3 \\
\hline 11 & $\begin{array}{l}\mathrm{SCZ} \\
\mathrm{BIP} \\
\mathrm{DEP}\end{array}$ & $\begin{array}{l}113185591-113692660 \\
113241877-113451229 \\
113166310-113692660\end{array}$ & rs 2514218 & $\begin{array}{l}7.37 \mathrm{e}^{-7} \\
0.001 \\
0.0015\end{array}$ & $\begin{array}{l}\text { TRUE } \\
\text { TRUE } \\
\text { TRUE }\end{array}$ & $\begin{array}{l}\mathrm{X} \\
\mathrm{X} \\
\mathrm{X}\end{array}$ & $\mathrm{x}$ & $\begin{array}{c}\text { TTC12, DRD2, AP002884.3, BCO2, } \\
\text { PLET1, AP002884.2, TMPRSS5, } \\
\text { ZBTB16 }\end{array}$ \\
\hline 12 & $\begin{array}{l}\text { SCZ } \\
\text { BIP } \\
\text { DEP }\end{array}$ & $\begin{array}{l}2474661-2523772 \\
2474661-2523772 \\
2465364-2523772\end{array}$ & rs2239063 & $\begin{array}{l}0.038 \\
0.043 \\
0.016\end{array}$ & $\begin{array}{l}\text { TRUE } \\
\text { TRUE } \\
\text { TRUE }\end{array}$ & $\begin{array}{l}\mathrm{X} \\
\mathrm{X} \\
\mathrm{X}\end{array}$ & TRUE & CACNA1C \\
\hline $18^{\mathrm{b}}$ & $\begin{array}{l}\text { SCZ } \\
\text { BIP } \\
\text { DEP }\end{array}$ & $\begin{array}{l}50517509-51055069 \\
50711776-50907127 \\
50358109-51055069\end{array}$ & rs1367635 & $\begin{array}{c}0.0032 \\
0.034 \\
0.0035\end{array}$ & $\begin{array}{l}\text { TRUE } \\
\text { TRUE } \\
\text { TRUE }\end{array}$ & $\begin{array}{l}x \\
X \\
X\end{array}$ & $\mathrm{x}$ & $D C C$ \\
\hline $18^{\mathrm{b}}$ & $\begin{array}{c}\text { SCZ } \\
\text { DEP } \\
\text { ADHD }\end{array}$ & $\begin{array}{l}50517509-51055069 \\
50197439-51055069 \\
50358109-51055069\end{array}$ & rs7506904 & $\begin{array}{l}0.049 \\
0.048 \\
0.046\end{array}$ & $\begin{array}{l}\text { TRUE } \\
\text { TRUE } \\
\text { TRUE }\end{array}$ & $\begin{array}{l}\mathrm{X} \\
\mathrm{x} \\
\mathrm{X}\end{array}$ & $\mathrm{x}$ & $D C C$ \\
\hline 18 & $\begin{array}{l}\text { SCZ } \\
\text { BIP } \\
\text { DEP }\end{array}$ & $\begin{array}{l}52720948-53474904 \\
52720948-52827668 \\
52520149-53424880\end{array}$ & rs4505420 & $\begin{array}{l}0.0032 \\
0.0083 \\
0.0098\end{array}$ & $\begin{array}{l}\text { TRUE } \\
\text { TRUE } \\
\text { TRUE }\end{array}$ & $\begin{array}{c}\mathrm{x} \\
\text { TRUE } \\
\mathrm{x}\end{array}$ & $\mathrm{x}$ & $R A B 27 B, T X N L 1, W D R 7$ \\
\hline 20 & $\begin{array}{c}\text { SCZ } \\
\text { BIP } \\
\text { ADHD }\end{array}$ & $\begin{array}{l}44680853-44749251 \\
44680412-44747947 \\
44680853-44749251\end{array}$ & rs6032660 & $\begin{array}{l}0.044 \\
0.047 \\
0.042\end{array}$ & $\begin{array}{l}\text { TRUE } \\
\text { TRUE } \\
\text { TRUE }\end{array}$ & $\begin{array}{c}\text { TRUE } \\
\mathrm{x} \\
\mathrm{x}\end{array}$ & $\mathrm{x}$ & $\begin{array}{l}\text { SLC12A5, CD40, UBE2C, ZSWIM1, } \\
\text { SPATA25, NEURL2, CTSA, PCIF1, } \\
\text { AL162458.1, NCOA5, ELMO2 }\end{array}$ \\
\hline 22 & $\begin{array}{l}\text { SCZ } \\
\text { BIP } \\
\text { DEP }\end{array}$ & $\begin{array}{l}41080566-42248289 \\
41080566-41404511 \\
41080566-42216326\end{array}$ & rs80533 & $\begin{array}{c}0.01 \\
0.021 \\
0.0067\end{array}$ & $\begin{array}{l}\text { TRUE } \\
\text { TRUE } \\
\text { TRUE }\end{array}$ & $\begin{array}{l}\mathrm{X} \\
\mathrm{X} \\
\mathrm{X}\end{array}$ & $\mathrm{x}$ & $\begin{array}{c}\text { MCHR1, SLC25A17, XPNPEP3, } \\
\text { RBX1, EP300, L3MBTL2, } \\
\text { RANGAP1, ZC3H7B, SGSM3, TOB2, } \\
\text { PHF5A, ACO2, POLR3H, MEI1, } \\
W B P 2 N L \\
\end{array}$ \\
\hline
\end{tabular}

Table 2: Transdiagnostic loci jointly associated with mood instability (MOOD) and psychiatric disorders (Psych) across three or more disorders. Minimum and maximum base pairs (BPs), "transdiagnostic lead SNPs" and conjunctional false discovery statistics (conjFDR) are presented for each locus. The concordance of effect direction and novelty of a locus for MOOD and each Psych is indicated by "TRUE”. Protein-coding genes mapped to candidate SNPs from each MOOD/Psych analysis are presented. If there were no protein-coding genes mapped to a locus, non-protein coding mapped genes are presented $\left({ }^{a}\right)$. Genes mapped by all three mapping strategies (credible genes) are in bold. ${ }^{b}$ Loci are physically overlapping but there was no candidate SNP with conjFDR $<0.05$ across all four analyses. Locus spans 8 p23 inversion region with complex linkage disequilibrium. This biases gene-mapping strategies so only a single mapped gene is presented. 
medRxiv preprint doi: https://doi.org/10.1101/2021.07.16.21260608; this version posted July 19, 2021. The copyright holder for this preprint (which was not certified by peer review) is the author/funder, who has granted medRxiv a license to display the preprint in perpetuity.

It is made available under a CC-BY-NC-ND 4.0 International license .
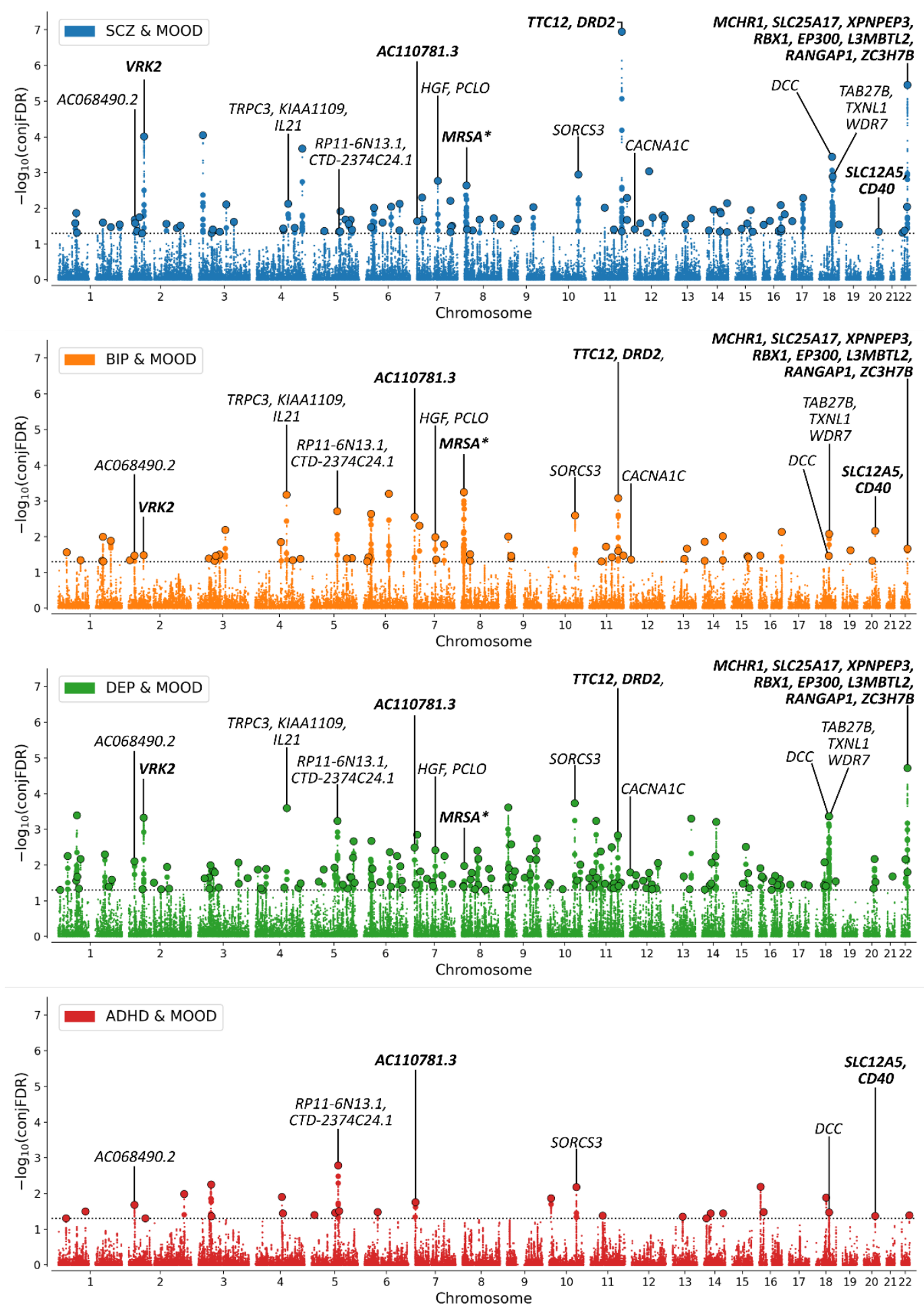

Figure 3: Manhattan plot showing - $\log 10$ transformed conjunctional FDR (conjFDR) values for mood instability (MOOD) and $\boldsymbol{a}$ ) schizophrenia (SCZ, blue) b) bipolar disorder (BIP, orange) $\boldsymbol{c}$ ) major depression (DEP, green) and $\boldsymbol{d}$ ) attention-deficit hyperactivity disorder (ADHD, red) for each SNP (y axis) against chromosomal position (x axis). The dotted line represents conjFDR $<0.05$ significance threshold. Black circles represent lead SNPs. Lead SNPs from transdiagnostic loci across three or more disorders are annotated with mapped genes. N.B. Not all mapped genes for each locus are presented due to space limitations. Credible genes (bold) were prioritised followed by protein-coding genes and then non-protein-coding genes. * Locus spans 8p23 inversion region with complex linkage disequilibrium. This biases gene-mapping strategies so only a single mapped gene is presented. 
medRxiv preprint doi: https://doi.org/10.1101/2021.07.16.21260608; this version posted July 19, 2021. The copyright holder for this preprint (which was not certified by peer review) is the author/funder, who has granted medRxiv a license to display the preprint in perpetuity.

It is made available under a CC-BY-NC-ND 4.0 International license .

\section{DISCUSSION}

In this combined GWAS analysis, we used MiXeR to reveal extensive polygenic overlap between MOOD and each of SCZ, BIP, DEP and ADHD despite divergent patterns of genetic correlations. A large proportion of the genetic variants linked to psychiatric disorders also influence MOOD, but the number of shared and trait specific variants and the balance of protective and risk-enhancing variants differ across diagnostic groups. Using conjFDR, MOOD was jointly associated with SCZ at 163 loci, BIP at 60 loci, DEP at 163 loci and ADHD at 28 loci, representing 259 unique genomic loci jointly associated with MOOD and psychiatric disorders. Of these, 220 were novel in MOOD and 152 were novel in psychiatric disorders. Replication analysis provided evidence of consistent genetic effects in independent SCZ, BIP and DEP samples. We identified 53 transdiagnostic loci that were overlapping across MOOD and two or more psychiatric disorders, implicating 1179 putative transdiagnostic genes with an apparent convergence on synaptic gene-sets, although a divergent pattern of effect directions persisted within shared gene-sets. These findings have implications for how the genetic risk of mentalhealth related traits is conceptualized and suggests differences in the neurobiological basis of MOOD across different psychiatric disorders, including the possibility of genetically influenced sub-groups of patients with more or less prominent MOOD. We also highlight genes that are likely to influence MOOD across several diagnoses, indicating high relevance for future in vitro and in vivo investigation.

Firstly, 55\%-97\% of disorder associated variants were predicted to influence MOOD, raising questions about the specificity of the genetic architecture of these complex polygenic psychiatric disorders and related traits. Our findings compliment evidence that a large proportion of genetic variants are not unique for a given mental trait or disorder $(26,40)$, but influence multiple mental phenotypes to different degrees. As such, the distinct SNP-based risk profiles for different mental-health related traits are not merely defined by unique non-overlapping sets of genetic variants, but largely accounted for by a set of pleiotropic non-specific genetic variants showing different strengths of association and effect across these phenotypes (26). Although this hypothesis warrants further interrogation, it suggests that novel approaches are needed to account for the substantial pleiotropy we predict in order to robustly distinguish the genetic risk for different mental traits and disorders. ${ }^{26}$ Furthermore, this places emphasis 
medRxiv preprint doi: https://doi.org/10.1101/2021.07.16.21260608; this version posted July 19, 2021. The copyright holder for this preprint (which was not certified by peer review) is the author/funder, who has granted medRxiv a license to display the preprint in perpetuity. It is made available under a CC-BY-NC-ND 4.0 International license .

on identifying disease specific variants that may disproportionately affect the development of a specific phenotype, individually and/or collectively, to inform precision medicine approaches in psychiatry.

Secondly, MOOD has gained interest due to its prevalence across diagnoses and its prominent neurobiological basis (14), implying that it may represent a novel treatment target $(2,14)$. To some extent, this is supported by the large degree of shared genomic loci and corresponding mapped genes identified. However, there were differences in genetic correlations and effect directions of shared loci, with stronger positive correlations and higher proportions of loci with concordant effects in DEP and ADHD compared to weak correlations and lower proportions of loci with concordant effects in SCZ and BIP. This pattern persisted within specific gene-sets identified across multiple analyses. This implies that there may be mechanistic differences in MOOD across the four psychiatric disorders. It is important to note that this measure only reflects one aspect of MOOD, which may explain the lack of correlation with SCZ and BIP, particularly given MOOD's strong clinical association with BIP. Nonetheless, it is tempting to speculate that MOOD experienced in DEP and ADHD has a similar neurobiological relationship whereas MOOD in BIP and SCZ may reflect a different underlying aetiological mechanism. This is relevant as such differences may limit the potential for transdiagnostic pharmacological interventions. Alternatively, the current findings are also consistent with subgroups characterised by higher or lower MOOD within diagnostic categories, in line with clinical observations (41). Above all, these findings emphasise the importance of exploring the neurobiological and phenomenological differences in MOOD across diagnostic groups.

To characterise MOOD's neurobiological underpinnings, we used three gene-mapping strategies to identify credible mapped genes for all jointly associated loci. Among these, AC110781.3 was mapped to a non-synonymous exonic SNP jointly associated with MOOD and all four psychiatric disorders. AC110781.3 is a protein-coding gene of unknown function that is expressed in the cortex, amygdala and hippocampus. In addition to previously being implicated in schizophrenia (42) and risk-taking behaviour (43), we also recently linked $A C 110781.3$ to multiple sleep phenotypes and BIP, DEP and SCZ in an analysis of the genetic overlap between sleep-related phenotypes and psychiatric disorders. This suggests $A C 110781.3$ influences multiple diverse phenotypes and may represent a promising 
medRxiv preprint doi: https://doi.org/10.1101/2021.07.16.21260608; this version posted July 19, 2021. The copyright holder for this preprint (which was not certified by peer review) is the author/funder, who has granted medRxiv a license to display the preprint in perpetuity.

It is made available under a CC-BY-NC-ND 4.0 International license .

candidate for further in vitro and in vivo investigation. We also identified several well-established psychiatric risk genes, including VRK2 (39), CACNAIC (44), and DRD2 (45), although an association with mood instability has not previously been described in the literature. The convergence of transdiagnostic mapped genes on synaptic structure builds on Ward et al.'s finding in the primary mood instability GWAS that mapped genes were associated with synaptic transmission.

Finally, while mood instability has a prominent genetic component, it remains influenced by environmental factors $(12,18)$. Future work focusing on gene-environmental interplay, particularly in relation to childhood trauma which has been found to correlate with the development of mood instability (46), would be of high interest.

There were limitations to the current study. Firstly, due to available sample sizes and multi-ancestral differences in LD structure we were unable to include multi-ancestral samples. This is an essential area for improvement in psychiatric genetics. Secondly, due to the small sample size of the most recent borderline personality disorder GWAS ( $\mathrm{n}=2$ 579), we were unable to include it in the current analysis despite its primacy in MOOD (2). This analysis should be repeated as sample sizes increase to include other relevant disorders, identify more transdiagnostic loci, and validate MiXeR's predictions. Thirdly, the measure of MOOD was based on a single, binary questionnaire item that did not measure affect intensity, regulation of affect or behavioural sequelae, and did not specify the timeframe (1). This may have contributed to the lack of genetic correlations with SCZ and BIP. Nonetheless, a simple measure was necessary to achieve a large enough sample size to achieve a genome-wide signal. Previous GWAS using more complete measures have substantially smaller sample sizes and failed to identify genomewide significant loci (47). Moreover, the same binary questionnaire item is associated with BIP and DEP, demonstrating its clinical relevance. Future work with more refined measures is required to understand how these findings relate to other dimensions of MOOD. Finally, differences in sample size affect conjFDR's power to discover shared loci. This precludes cross-analysis comparisons of the number of loci discovered by conjFDR. The disparity between the number of shared loci discovered and the number of shared variants predicted by MiXeR also indicates that we cannot confidently identify loci "unique" to each mental disorder, since it is possible that the lack of association is due to type II 
medRxiv preprint doi: https://doi.org/10.1101/2021.07.16.21260608; this version posted July 19, 2021. The copyright holder for this preprint (which was not certified by peer review) is the author/funder, who has granted medRxiv a license to display the preprint in perpetuity.

It is made available under a CC-BY-NC-ND 4.0 International license .

error. This will only be addressed once larger proportions of disorder-influencing variants have been discovered.

In conclusion, we have discovered extensive polygenic overlap between MOOD and psychiatric disorders with divergent patterns of genetic correlation and effect directions. These results support the notion that there are common molecular pathways implicated in MOOD across diagnostic categories, but disorder specific effect size distributions indicate key differences in MOOD's neurobiological underpinnings across diagnoses.

\section{ACKNOWLEDGEMENTS}

We would like to thank Dr. Yunhan Chu for her thoughtful contributions to the manuscript. We thank the research participants and employees of the Schizophrenia, Depression and Bipolar Disorder Working Groups of the Psychiatric Genomics Consortium, 23andMe, UK Biobank, and FinnGen for making this research possible. We gratefully acknowledge support from the American National Institutes of Health (NS057198, EB00790), the Research Council of Norway (229129, 213837, 223273), the South-East Norway Regional Health Authority (2017-112), KG Jebsen Stiftelsen (SKGJMED-008) and the PGC US Norway Collaboration (RCN\# 248980). This project has received funding from the European Union's Horizon 2020 research and innovation programme under grant agreement No 847776. This research has been conducted using data from UK Biobank, a major biomedical database (Project ID number 27412; www.ukbiobank.ac.uk).

\section{DISCLOSURES}

O.A.A. has received speaker's honorarium from Lundbeck and is a consultant for Healthlytix. A.M.D. is a founder of and holds equity interest in CorTechs Labs and serves on its scientific advisory board. He is also a member of the Scientific Advisory Board of Healthlytix and receives research funding from General Electric Healthcare (GEHC). The terms of these arrangements have been reviewed and approved by the University of California, San Diego in accordance with its conflict of interest policies. Remaining authors report no financial relationships with commercial interests. 


\section{REFERENCES}

1. Marwaha S, He Z, Broome M, Singh SP, Scott J, Eyden J, Wolke D (2014): How is affective instability defined and measured? A systematic review. Psychol Med 44: 1793-1808.

2. Koenigsberg HW (2010): Affective instability: Toward an integration of neuroscience and psychological perspectives. J Pers Disord 24: 60-82.

3. Marwaha S, Parsons N, Flanagan S, Broome M (2013): The prevalence and clinical associations of mood instability in adults living in England: Results from the Adult Psychiatric Morbidity Survey 2007. Psychiatry Res 205: 262-268.

4. Patel R, Lloyd T, Jackson R, Ball M, Shetty H, Broadbent M, et al. (2015): Mood instability is a common feature of mental health disorders and is associated with poor clinical outcomes. BMJ Open 5. https://doi.org/10.1136/bmjopen-2014-007504

5. Høegh MC, Melle I, Aminoff SR, Laskemoen JF, Büchmann CB, Ueland T, Lagerberg TV (2020): Affective lability across psychosis spectrum disorders. Eur Psychiatry 1-17.

6. Thompson RJ, Berenbaum H, Bredemeier K (2011): Cross-sectional and longitudinal relations between affective instability and depression. J Affect Disord 130: 53-59.

7. Skirrow C, McLoughlin G, Kuntsi J, Asherson P (2009): Behavioral, neurocognitive and treatment overlap between attention-deficit/hyperactivity disorder and mood instability. Expert Rev Neurother 9: 489-503.

8. Angst J, Gamma A, Endrass J (2003): Risk factors for the bipolar and depression spectra. Acta Psychiatr Scand 108: 15-19.

9. Bonsall MB, Wallace-Hadrill SMA, Geddes JR, Goodwin GM, Holmes EA (2012): Nonlinear timeseries approaches in characterizing mood stability and mood instability in bipolar disorder. Proc R Soc B Biol Sci 279: 916-924.

10. Henry C, Van den Bulke D, Bellivier F, Roy I, Swendsen J, M'Baïlara K, et al. (2008): Affective lability and affect intensity as core dimensions of bipolar disorders during euthymic period. Psychiatry Res 159: 1-6.

11. Marwaha S, Parsons N, Broome M (2013): Mood instability, mental illness and suicidal ideas: Results from a household survey. Soc Psychiatry Psychiatr Epidemiol 48: 1431-1437.

12. Coccaro EF, Ong AD, Seroczynski AD, Bergeman CS (2012): Affective intensity and lability: heritability in adult male twins. J Affect Disord 136: 1011-1016.

13. Price TRP, Goetz KL, Lovell MR (2011): Brain tumors. Clinical Manual of Neuropsychiatry. American Psychiatric Press USA, pp 235-263.

14. Broome MR, He Z, Iftikhar M, Eyden J, Marwaha S (2015): Neurobiological and behavioural studies of affective instability in clinical populations: A systematic review. Neurosci Biobehav Rev 51: 243-254.

15. Harrison PJ, Geddes JR, Tunbridge EM (2018): The Emerging Neurobiology of Bipolar Disorder, 2017/11/20. Trends Neurosci 41: 18-30.

16. Das P, Calhoun V, Malhi GS (2014): Bipolar and borderline patients display differential patterns of functional connectivity among resting state networks. Neuroimage 98: 73-81.

17. Ward J, Strawbridge RJ, Bailey MES, Graham N, Ferguson A, Lyall DM, et al. (2017): Genomewide analysis in UK Biobank identifies four loci associated with mood instability and genetic correlation with major depressive disorder, anxiety disorder and schizophrenia. Transl Psychiatry 7: 1264.

18. Ward J, Tunbridge EM, Sandor C, Lyall LM, Ferguson A, Strawbridge RJ, et al. (2019): The genomic basis of mood instability: identification of 46 loci in 363,705 UK Biobank participants, 
medRxiv preprint doi: https://doi.org/10.1101/2021.07.16.21260608; this version posted July 19, 2021. The copyright holder for this preprint (which was not certified by peer review) is the author/funder, who has granted medRxiv a license to display the preprint in perpetuity. It is made available under a CC-BY-NC-ND 4.0 International license .

genetic correlation with psychiatric disorders, and association with gene expression and function. Mol Psychiatry 1-9.

19. Pardiñas AF, Holmans P, Pocklington AJ, Escott-Price V, Ripke S, Carrera N, et al. (2018): Common schizophrenia alleles are enriched in mutation-intolerant genes and in regions under strong background selection. Nat Genet 50: 381-389.

20. Stahl EA, Breen G, Forstner AJ, McQuillin A, Ripke S, Trubetskoy V, et al. (2019): Genome-wide association study identifies 30 loci associated with bipolar disorder. Nat Genet 51: 793-803.

21. Wray NR, Ripke S, Mattheisen M, Trzaskowski M, Byrne EM, Abdellaoui A, et al. (2018): Genome-wide association analyses identify 44 risk variants and refine the genetic architecture of major depression. Nat Genet 50: 668.

22. Girard SL, Xiong L, Dion PA, Rouleau GA (2011): Where are the missing pieces of the schizophrenia genetics puzzle? Curr Opin Genet Dev 21: 310-316.

23. Demontis D, Walters RK, Martin J, Mattheisen M, Als TD, Agerbo E, et al. (2019): Discovery of the first genome-wide significant risk loci for attention deficit/hyperactivity disorder. Nat Genet 51: $63-75$.

24. Frei O, Holland D, Smeland OB, Shadrin AA, Fan CC, Maeland S, et al. (2019): Bivariate causal mixture model quantifies polygenic overlap between complex traits beyond genetic correlation. Nat Commun 10: 1-11.

25. Smeland OB, Frei O, Shadrin A, O'Connell K, Fan C-C, Bahrami S, et al. (2019): Discovery of shared genomic loci using the conditional false discovery rate approach. Hum Genet 1-10.

26. Smeland OB, Frei O, Dale AM, Andreassen OA (2020): The polygenic architecture of schizophrenia - rethinking pathogenesis and nosology. Nature Reviews Neurology. Nature Research, pp 1-14.

27. Mullins N, Forstner AJ, O'Connell KS, Coombes B, Coleman JRI, Qiao Z, et al. (2021): Genomewide association study of more than 40,000 bipolar disorder cases provides new insights into the underlying biology. Nat Genet. https://doi.org/10.1038/s41588-021-00857-4

28. Yengo L, Sidorenko J, Kemper KE, Zheng Z, Wood AR, Weedon MN, et al. (2018): Meta-analysis of genome-wide association studies for height and body mass index in $~ 700000$ individuals of European ancestry. Hum Mol Genet 27: 3641-3649.

29. Lam M, Chen CY, Li Z, Martin AR, Bryois J, Ma X, et al. (2019): Comparative genetic architectures of schizophrenia in East Asian and European populations. Nat Genet 51: 1670-1678.

30. FinnGen (2020): FinnGen Documentation of R4 release. Retrieved January 27, 2021, from https://finngen.gitbook.io/documentation/

31. Andreassen OA, Harbo HF, Wang Y, Thompson WK, Schork AJ, Mattingsdal M, et al. (2015): Genetic pleiotropy between multiple sclerosis and schizophrenia but not bipolar disorder: differential involvement of immune-related gene loci, 2014/01/28. Mol Psychiatry 20: 207-214.

32. Ripke S, Walters JTR, O\&\#039;Donovan MC (2020): Mapping genomic loci prioritises genes and implicates synaptic biology in schizophrenia. medRxiv 2020.09.12.20192922.

33. Lee JJ, Wedow R, Okbay A, Kong E, Maghzian O, Zacher M, et al. (2018): Gene discovery and polygenic prediction from a genome-wide association study of educational attainment in 1.1 million individuals. Nat Genet 50: 1112-1121.

34. Savage JE, Jansen PR, Stringer S, Watanabe K, Bryois J, De Leeuw CA, et al. (2018): Genomewide association meta-analysis in 269,867 individuals identifies new genetic and functional links to intelligence. Nat Genet 50: 912-919.

35. Watanabe K, Taskesen E, van Bochoven A, Posthuma D (2017): Functional mapping and annotation of genetic associations with FUMA. Nat Commun 8: 1826.

36. Auton A, Abecasis GR, Altshuler DM, Durbin RM, Bentley DR, Chakravarti A, et al. (2015): A 
medRxiv preprint doi: https://doi.org/10.1101/2021.07.16.21260608; this version posted July 19, 2021. The copyright holder for this preprint (which was not certified by peer review) is the author/funder, who has granted medRxiv a license to display the preprint in perpetuity. It is made available under a CC-BY-NC-ND 4.0 International license.

global reference for human genetic variation. Nature 526: 68-74.

37. Bahrami S, Shadrin A, Frei O, O'Connell KS, Bettella F, Krull F, et al. (2021): Genetic loci shared between major depression and intelligence with mixed directions of effect. Nat Hum Behav 1-7.

38. Holland D, Frei O, Desikan R, Fan C-C, Shadrin AA, Smeland OB, et al. (2020): Beyond SNP heritability: Polygenicity and discoverability of phenotypes estimated with a univariate Gaussian mixture model ((X. Zhu, editor)). PLOS Genet 16: e1008612.

39. Li M, Yue W (2018): VRK2, a Candidate Gene for Psychiatric and Neurological Disorders. Mol Neuropsychiatry 4: 119-133.

40. Smeland OB, Frei O, Fan CC, Shadrin A, Dale AM, Andreassen OA (2020): The emerging pattern of shared polygenic architecture of psychiatric disorders, conceptual and methodological challenges. Psychiatric Genetics, vol. 29. Lippincott Williams and Wilkins, pp 152-159.

41. Ducasse D, Jaussent I, Guillaume S, Azorin JM, Bellivier F, Belzeaux R, et al. (2017): Affect lability predicts occurrence of suicidal ideation in bipolar patients: a two-year prospective study. Acta Psychiatr Scand 135: 460-469.

42. Huckins LM, Dobbyn A, Ruderfer DM, Hoffman G, Wang W, Pardiñas AF, et al. (2019): Gene expression imputation across multiple brain regions provides insights into schizophrenia risk. Nat Genet 51: 659-674.

43. Karlsson Linnér R, Biroli P, Kong E, Meddens SFW, Wedow R, Fontana MA, et al. (2019): Genome-wide association analyses of risk tolerance and risky behaviors in over 1 million individuals identify hundreds of loci and shared genetic influences. Nat Genet 51: 245-257.

44. Moon AL, Haan N, Wilkinson LS, Thomas KL, Hall J (2018): CACNA1C: Association with psychiatric disorders, behavior, and neurogenesis. Schizophr Bull 44: 958-965.

45. Psychiatric SWG of the, Ripke S, Neale BM, Corvin A, Walters JTR, Farh K-H, et al. (2014): Biological insights from 108 schizophrenia-associated genetic loci. Nature 511: 421.

46. Marwaha S, Gordon-Smith K, Broome M, Briley PM, Perry A, Forty L, et al. (2016): Affective instability, childhood trauma and major affective disorders. J Affect Disord 190: 764-771.

47. Gisbert L, Vilar L, Rovira P, Sánchez-Mora C, Pagerols M, Garcia-Martínez I, et al. (2019): Genome-wide analysis of emotional lability in adult attention deficit hyperactivity disorder (ADHD). Eur Neuropsychopharmacol 29: 795-802. 